Border Dilemmas 



\title{
BORDER DILEMMAS
}

\author{
Racial and National Uncertainties
}

in New Mexico, 1848-1912

\author{
Anthony Mora \\ Duke University Press \\ Durham and London \\ 2011
}


(C) 2011 Duke University Press

All rights reserved

Printed in the United States of America on acid-free paper $\infty$

Designed by C. H. Westmoreland

Typeset in Warnock Pro with Gill Sans display by Keystone Typesetting, Inc.

Library of Congress Cataloging-in-Publication Data appear on the last printed page of this book.

An earlier version of Chapter 3 appeared as "Resistance and Accommodation in a

Border Parish,” Western Historical Quarterly 36 (autumn 2005): 301-26.

Duke University Press gratefully acknowledges the support of the University of Michigan, Program in American Culture, which provided funds toward the production of this book. 
To my sister, Marie 
